\title{
THE EFFECT OF REINVENTING POTENTIAL AND FINANCIAL INDEPENDENCE ON THE ENTREPRENEURS CHARACTER OF MILLENNIALS THROUGH SOCIAL MEDIA IN THE ERA MARKETING 4.0
}

\author{
Adnan $^{1}$, Aiyub Yahya ${ }^{2}$ \\ ${ }^{1,2}$ Faculty of economic and Business Universitas Malikussaleh \\ Email: adnan@unimal.ac.id
}

\begin{abstract}
The study presents the results of the impact of reinventing potential and financial independence on the entrepreneur character of millennial generation through social media in the era marketing 4.0. The data were obtained from a survey of 448respondents(student) from fourdepartement of Faculty Economic and Bussiness Malikussaleh University in Indonesia. The following statistical methods were used: descriptive statistics and structural eqution modelling analysis. The study found that reinventing potential, financial independence and social media has a significant effect on the entrepreneurial character of the millennial generation in IndonesiaAnother finding: Social media did not moderate the relationship between reinventing potential and the entrepreneurial character of the millennial generation, but social media was found to moderate the relationship between financial indenpendence and the entrepreneurial character of the millennial generation in the marketing era 4.0 .
\end{abstract}

Keywords: reinfenting potential, financial independence, social media, entrepreneur character and marketing 4.0.

\section{INTRODUCTION}

Indonesia is one of the countries with the largest population, namely 267 million people (2020). A large population allows for the creation of a demographic bonus. This is an opportunity for Indonesia to advance the economy through investment in human resources, especially for the millennial generation born in the 1980-2000 range with a percentage of 33.75\%. Apart from that, Indonesia also ranks sixth-largest internet users in the world. Hidayat (2014) explained that internet users in Indonesia reached 106 million of the world's 3.6 billion population. The percentage of the millennial generation in Indonesia who use the internet reaches 91.62 percent. In essence, the millennial generation is a great asset to realize the independence of the nation in all aspects. As the main capital for national development, it is hoped that the millennial generation has superior potential in Industry 4.0 compared to the previous generation.Marketing has developed rapidly from being product oriented in the marketing 1.0 era, to being customer oriented in the marketing 4.0. Marketing approach 4.0, combines human touch to consumers through technological sophistication.

The readiness of this millennial generation to interact with other resources such as technological sophistication is the main asset today. In addition, these conditions can create a conducive environment for building healthy, intelligent, and productive human resources capable of mastering science and technology. The maximized potential of the millennial generation will be able to increase economic growth.

Millennials born and raised in the strong current of technological developments. Their attitudes and behavior are much influenced by gadgets and the internet. They tend to be more concerned with the use of technology, taste in music, and lifestyle. The choices they make are largely based on information from the internet, particularly social media. This can be a plus. Young people who are so familiar with technology can easily access information, via their smartphones, but this can backfire too. The reason is, the amount of information creates a consumptive lifestyle. Various attractive offers that appear on the smartphone screen make for impulsive buying, buying lifestyle, experience, and self-existence. Even though many predict, the millennial generation will experience 
The Effect of Reinventing Potential and Financial Independence on the Entrepreneurs Character of Millennials Through Social Media in the Era Marketing 4.0

DOI: $10.54443 /$ morfai.v1i2.104

financial difficulties.For Aceh Province, the number of millennials is around 35.92 percent above the national average of $33.75(1,855,720)$.

Rapid technological developments have not only changed the way we access information, but also the way we view the world. Several decades ago we had never heard of the term Facebook, Instagram smartphone, and online shops, and others, but now the term is familiar in our daily lives. This is in accordance with the view of Mc Luhan who argues that cultural change in human life is determined by technology and we will be in the midst of a revolution (technology

According to Papp and Matulich (2011), the use of technology by the millennial generation is not the same as the previous generation. Millennials use technology as part of their daily life. The use of technology by the millennial generation should not only be hedonistic but how they can use this technology to be more creative in using it more optimally so that it has an impact on their financial freedom.

This will be realized if the millennial generation has an entrepreneurial spirit that is able to see the future. Going forward, namely calculative thinking that is trusting (determination), optimistic, hard work, motivation, energetic, full of initiative. The high utilization of the internet by the millennial generation can be a solution for them in doing business that is balanced with social media management capabilities, such as Friendster, Facebook, MySpace, and Twitter. The use of social media needs to be encouraged by the millennial generation in doing business or doing business by opening online businesses, their participation in cyberspace as digital natives, Helsper \& Enyon (2009),

Based on data from the millennial generation who became entrepreneurs, it increased from 21.57 percent in 2015 to 24.33 percent in 2017 . The relatively small percentage of the working millennial generation chose to become entrepreneurs when compared to the previous generation, this shows that there is interest in entrepreneurship for the millennial generation is still lacking. This is most likely because the millennial generation is still inexperienced. In addition, the factor of fear of failure because of having to take risks could be another factor in the low interest of the millennial generation in entrepreneurship.

\section{THEORETICAL BACKGROUND AND HYPHOTHESIS}

1. Reinventing Potential

Reinventing is defined as rearranging, or in the sense of language is finding or re-creating or something which means entrepreneurship. (Senain, 2013; David, 1995). The concept is to rearrange the potential of human resources that have not been used properly (reinventing human resources) (Kearne, (2000). David Osborne and Ted Gaebler, in their book Reinventing Government: How the entrepreneurial spirit is transforming the public sector, say that the problem that often arises in understanding Reinventing Human Resources is how to empower the millennial generation in utilizing social media for their financial independence.

2. Financial Independence

Financial independence is the status of having enough income to pay for living expenses for the rest of your life without having to work or depend on other people. (Robin \& Dominguez, 1992) Income earned without having to work in a job is usually referred to as passive income.There are many strategies for achieving financial independence, each with its own advantages and disadvantages. A person looking to achieve financial independence can find it helpful to have a financial plan and budget, so that they have a clear view of their current income and expenses, and can identify and choose the right strategy for moving towards their financial goals. The financial plan addresses every aspect of a person's finances. (Fisker, 2010). Financial independence is when a person has large and relatively safe savings, and the results are sufficient to live the desired lifestyle. Financial independence can also be interpreted as the phase when we are calm and the choice to stop working for money because money is what works for us 
(passive income). What is meant by passive income here is money received without having to work. There are several ways that can be done to achieve financial independence, namely investing and owning productive assets.

3. Inteprenuers Character

In Dornal's Pocket Medical Dictionary, it is stated that character is a real and different characteristic shown by an individual or a number of attributes that can be observed in a person. According to Musrifa (2016), a character can also mean letters, numbers, spaces, special symbols that can be displayed on the screen with a keyboard, a person with a character means a person with personality or behavior.Siagian (1999) defines entrepreneurship as the spirit, behavior, and ability to give a positive response to opportunities for self-benefit and/or better service to customers/society, by always trying to serve good customers and creating and providing more useful products. and adopting more efficient ways of working, through the courage to take risks, creativity, and innovation and management skills. Lupiyoadi (2007: 2) states that the term entrepreneurship in Indonesian has several words that are often interpreted the same, including entrepreneur, entrepreneur, trader, trader, and finally entrepreneurship. Entrepreneurship or entrepreneurship is a person who has the courage to take risks by opening a business on various occasions. Some of the results of related previous research, Ambawati, (2020) who examined Building Entrepreneurial Spirit in the Millennial Era found that the era of globalization provides opportunities for millennials to be able to develop various technologybased businesses. Digital technology has become a new need and lifestyle for people who take advantage of opportunities to work in various fields that are more productive and creative. These actions can result in new innovations in building a business or developing an existing business. The same conclusion is also presented in the research results of Farhadiba (2019) and Students (2019).

4. Social Media

McGraw Hill Dictionary - Social media is a tool by which people interact with one another by creating, sharing, and exchanging information and ideas in a virtual network and community. Meanwhile, Hopkins, 2008), describes social media as a term that not only includes various new media platforms but also implies the inclusion of systems such as FriendFeed, Facebook, and others which are generally considered social networks. The idea is that various media platforms have a social component and serve as a medium for public communication. Kotler (2019), social media is the media used by consumers to share text, images, sound, and video information with other people and companies

5. Conceptual Framework and Hypothesis

This research was built based on theoretical and empirical studies, in which this research consists of 4 variables, namely two exogenous variables (Reinventing potential and Financial independence), one endogenous variable (entrepreneurial character), and one moderating variable (social media). The social media variable also doubles as an exogenous variable. The research conceptual framework is shown in Figure 1.

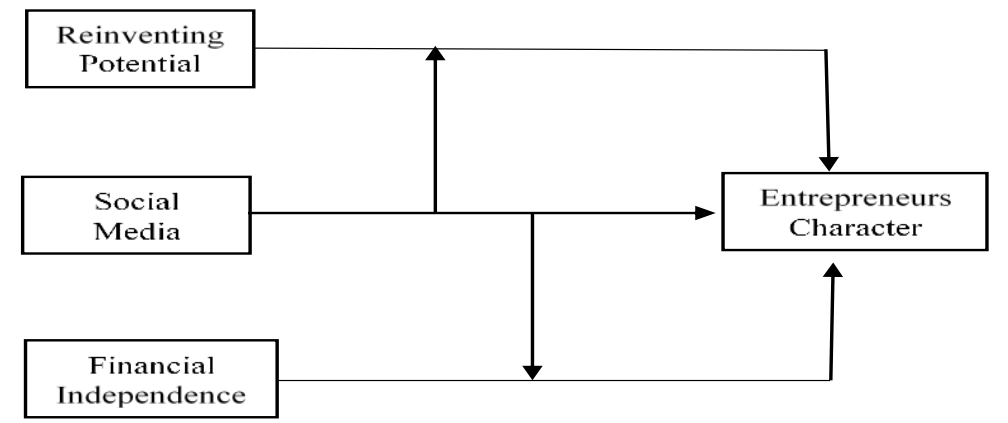

Figure 1.Research conceptual framework 
The Effect of Reinventing Potential and Financial Independence on the Entrepreneurs Character of Millennials Through Social Media in the Era Marketing 4.0

DOI: $10.54443 /$ morfai.v1i2.104

Based on the theory, empirical and conceptual framework of the research above, the hypothesis of this research is compiled as follows:

1. Reinventing potential has a significant effect on the entrepreneurial character of millennial generation in Aceh Indonesia.

2. Financial independence has a significant effect on the entrepreneurial character of millennial generation in Aceh Indonesia.

3. Social media has a significant effect on the entrepreneurial character of the millennial generation of Aceh Indonesia.

4. Social media moderates the effect of potential reinventing on the entrepreneurial character of the millennial generation in Aceh Indonesia.

5. Social media moderated the influence of financial independence on the entrepreneurial character millennial generation in Aceh Indonesia.

\section{RESEARCH METHODS}

To measure the reinventing potential variable, researchers used indicators based on the opinion of Osborne and Gaebler 2008, namely have creative and innovative ideas, be able to modify ideas, re-evaluate ideas, and have diverse potential. To measure social media variables using indicators from Kotler (2009) and Armstrong, (2001), namely love doing business through social media, believe in social media in doing business, social media provides a variety of information, social media comfort level, and easy to collaborate. To measure the variable of financial independence using the opinion of Kotler (2006), namely: have a formal financial account, have access to investment, have health insurance, easy access to loan funds and debt-free and has an emergency fund. The entrepreneurial character uses indicators developed by Rakib (2010), namely: confident, better result orientation, dare to take risks and challenges, have a leadership spirit, and optimism for success. Measurement indicators use a Likert scale consisting of $1=$ Strongly Disagree, $2=$ Disagree, $3=$ Neutral, $4=$ Agree and $5=$ Strongly Agree

The research was conducted in Lhokseumawe City and North Aceh, Aceh Province in Indonesia and the research sample was the millennial generation, which was 448 people. Where in general the sample is students at several universities in Indonesia.This study uses Structural Equation Modeling (SEM) for data analysis. To test the construct validity, Confirmatory Factor Analysis (CFA) was carried out by comparing the loading factor value of each indicator. An indicator is said to be valid if the loading factor value is> 0.60 and the convergent validity value is> 0.50 (Ghozali, 2014). Meanwhile, testing of construct validity was carried out with three tests, namely, variance extracted, construct reliability, and discriminant Validity.

\section{RESULTS}

\section{Descriptive Statistic}

Based on the data shown in Table 1, it can be explained that the standard deviation value of all indicators has a value that is smaller than the mean value of all indicators. This shows that all indicators in this study are normally distributed and share a good proportion among all indicators. 


\section{ORFAI JOURNAL Actual and International Issue}

Tabel 1. Statistic Descriptive Analysis

\begin{tabular}{|c|c|c|c|c|c|c|}
\hline Indicators & Short Name & $\mathrm{N}$ & Min & Max & Mean & $\begin{array}{l}\text { Std. } \\
\text { Deviation }\end{array}$ \\
\hline Have Creative and Innovative Ideas & RP1 & 448 & 1.00 & 5.00 & 4.272 & 0.807 \\
\hline Be able to modify ideas & RP2 & 448 & 1.00 & 5.00 & 3.991 & 0.800 \\
\hline Re-evaluate ideas & RP3 & 448 & 1.00 & 5.00 & 4.051 & 0.732 \\
\hline Has diverse potential & RP4 & 448 & 1.00 & 5.00 & 4.069 & 0.767 \\
\hline Have a formal financial account & FI1 & 448 & 1.00 & 5.00 & 3.489 & 0.849 \\
\hline Have access to investment & FI2 & 448 & 1.00 & 5.00 & 3.339 & 0.855 \\
\hline Has health insurance and insurance & FI3 & 448 & 1.00 & 5.00 & 3.567 & 0.922 \\
\hline Easy access to loan funds & FI4 & 448 & 1.00 & 5.00 & 3.328 & 0.911 \\
\hline Debt-free and has an emergency fund & FI5 & 448 & 1.00 & 5.00 & 3.547 & 1.046 \\
\hline Confident & $\mathrm{IC} 1$ & 448 & 1.00 & 5.00 & 4.107 & 0.837 \\
\hline Better result orientation & $\mathrm{IC} 2$ & 448 & 1.00 & 5.00 & 4.165 & 0.800 \\
\hline Dare to take risks and challenges & IC3 & 448 & 1.00 & 5.00 & 4.083 & 0.814 \\
\hline Have a leadership spirit & IC4 & 448 & 1.00 & 5.00 & 4.080 & 0.837 \\
\hline Optimism for success & IC5 & 448 & 1.00 & 5.00 & 4.154 & 0.831 \\
\hline Love doing business through social media & SM1 & 448 & 1.00 & 5.00 & 3.797 & 0.939 \\
\hline You believe in social media in doing business & SM2 & 448 & 1.00 & 5.00 & 3.513 & 0.877 \\
\hline Social media provides a variety of information & SM3 & 448 & 1.00 & 5.00 & 3.998 & 0.876 \\
\hline Social media comfort level & SM4 & 448 & 1.00 & 5.00 & 3.670 & 0.863 \\
\hline Social media is easy to collaborate with & SM5 & 448 & 1.00 & 5.00 & 3.920 & 0.904 \\
\hline
\end{tabular}

\section{Structural}

The full overall model is a structural equation model involving all research variables and taking into account social media variables in all categories, both low social media intensity and high social media intensity

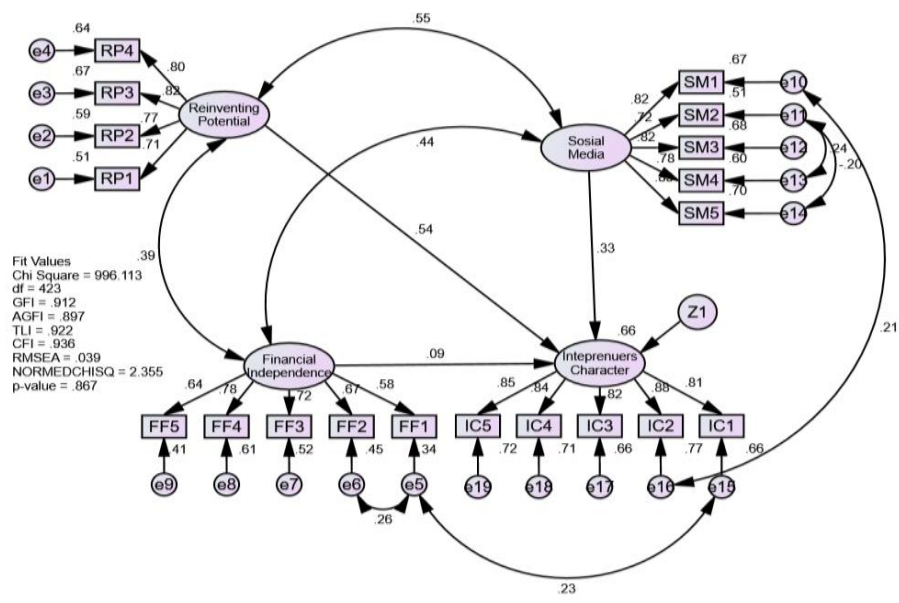

Figure 2. Full Overall Model (Low and High Social Media Intensity)

Based on the value shown in Figure 2 and Tabel 3, it can be explained that the effect of reinventing potential on entrepreneurial character is 0.54 with a probability value of 0.000 (significant at $1 \%$ ). The effect of financial independence on entrepreneurial character is 0.09 with a probability of 0.05 
The Effect of Reinventing Potential and Financial Independence on the Entrepreneurs Character of Millennials Through Social Media in the Era Marketing 4.0

DOI: 10.54443 /morfai.v1i2.104

(significant at 5\%), and the influence of social media on entrepreneurial character is 0.33 with a probability value of 0.000 (significant at $1 \%$ ).

Full Model (Low Social Media Intensity)

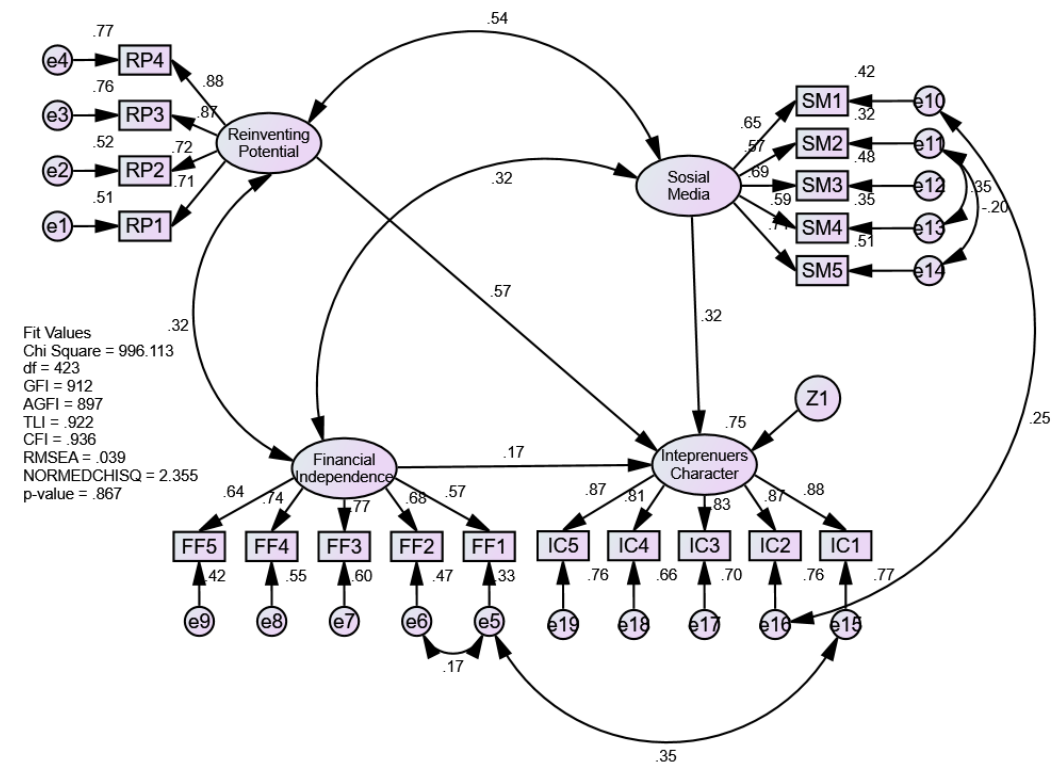

Figure 3. Full Model (Low Social Media Intensity)

Based on the value shown in Figure 3 and Tabel 3, it can be explained that the effect of reinventing potential on entrepreneurial character is 0.57 with a probability value of 0.000 (significant at $<1 \%$ ). The effect of financial independence on entrepreneurial character is 0.17 with a probability of 0.00 (significant at $1 \%$ ), and the effect of social media on entrepreneurial character is 0.32 with a probability value of 0.000 (significant at $1 \%$ ).

\section{Full Model (High Social Media Intensity)}

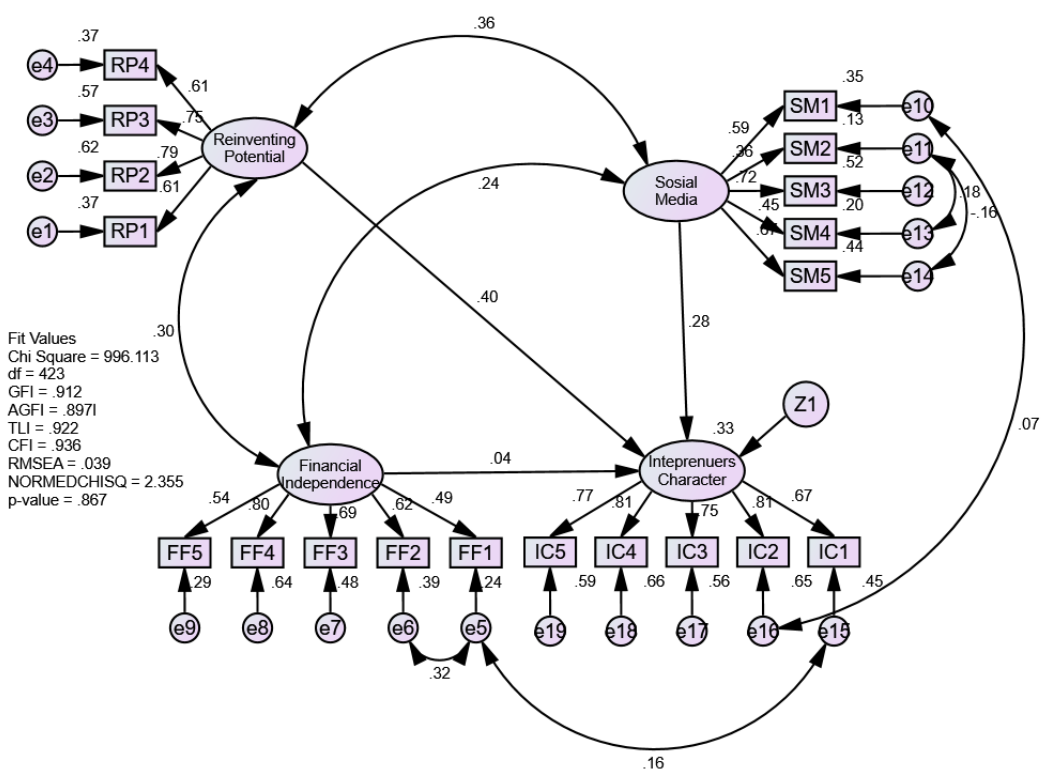

Figure 4. Full Model (High Social Media Intensity) 
Based on the value shown in Figure 4 and Tabel 3, it can be explained that the effect of reinventing potential on entrepreneurial character is 0.40 with a probability value of 0.000 (significant at $<1 \%$ ). The effect of financial independence on entrepreneurial character is 0.04 with a probability of 0.60 (not significant), and the effect of social media on entrepreneurial character is 0.37 with a probability value of 0.000 (significant at $<1 \%$ ).

Tabel 2. Goodness of Fit Indexs

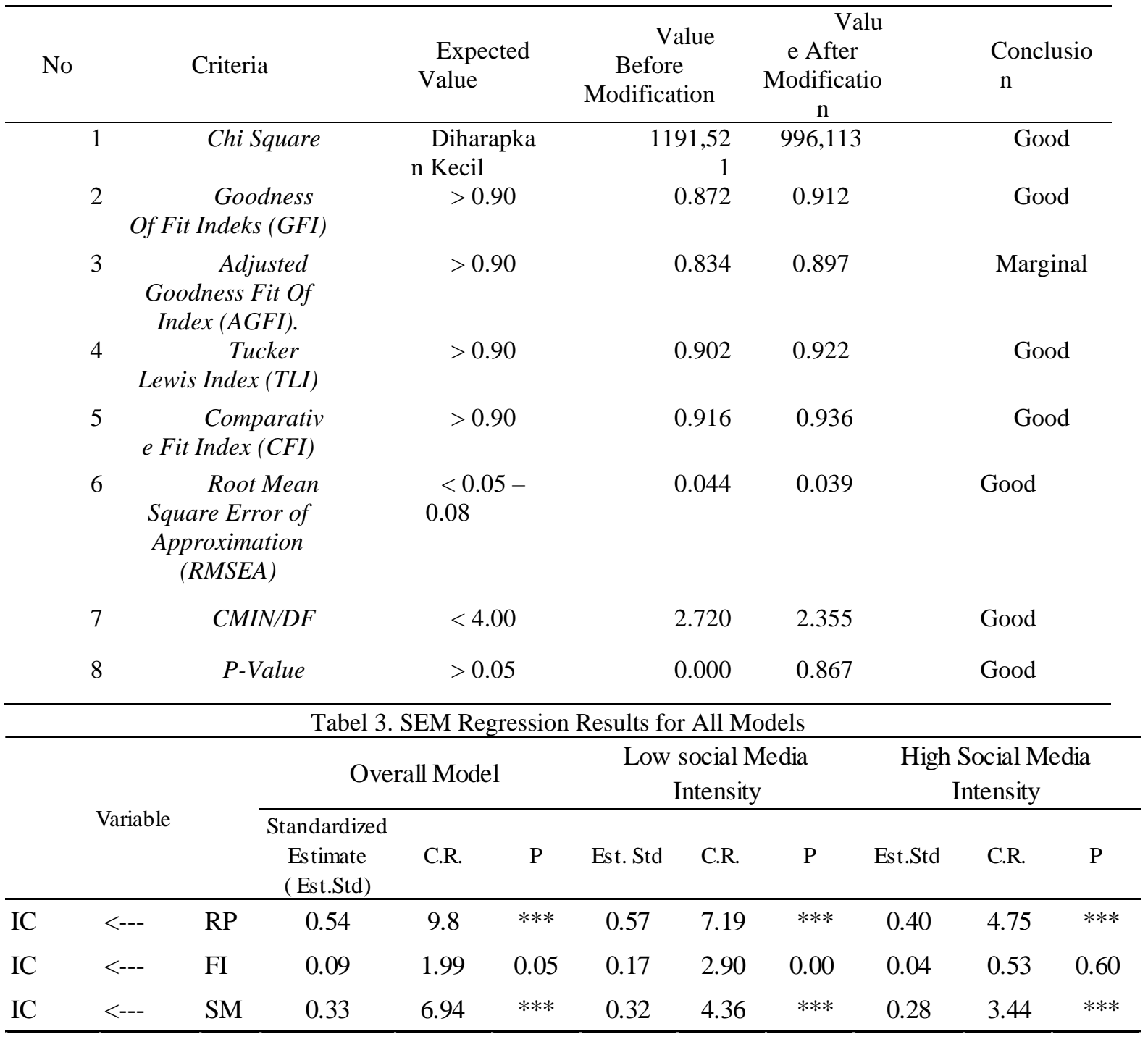

\section{DISCUSSION}

\section{Reinventing Potential and Entrepreneurs character}

The effect of reinventing potential on the entrepreneurial character is 0.54 with a probability value of 0.000 which is much smaller than 0.05 , meaning that reinventing potential has a positive and significant effect on the entrepreneurial character of the millennial generation. Reinventing potential activities have a positive impact on the growing interest of the millennial generation in entrepreneurship. Potential reinventing activities by creating a diversity of skills and expertise, equipping the millennial generation to generate creative ideas and the ability to modify ideas, and 
The Effect of Reinventing Potential and Financial Independence on the Entrepreneurs Character of Millennials Through Social Media in the Era Marketing 4.0

DOI: $10.54443 /$ morfai.v1i2.104

the ability to reassess big ideas will shape an entrepreneurial character that will lead to financial independence

\section{Financial Independence and Entrepreneurs character}

The effect of financial independence on the entrepreneurial character is 0.09 with a probability value of 0.05 which is equal to 0.05 , meaning that financial independence has a positive and significant effect on the entrepreneurial character of the millennial generation. These findings suggest that the millennial generation's desire for financial freedom will encourage them to become entrepreneurs. Most of the entrepreneurial activities of the millennial generation are through the use of social media. The use of social media in doing entrepreneurship is the most dominant feature of the millennial generation in doing business and creating.

\section{Social Media and Entrepreneurs character}

The influence of social media on the entrepreneurial character is 0.33 with a probability value of 0.000 which is much smaller than 0.05 , meaning that social media has a positive and significant effect on the entrepreneurial character of the millennial generation. Social media has become a necessity for millennials in their day-long activities. The presence of social media such as Facebook, Instagram, YouTube, and others has inspired them to apply creative and innovative ideas. Social media has a big influence on the desire of the millennial generation to carry out entrepreneurial activities

\section{Social Media as Moderating Variable}

1. The low social media intensity coefficient, the effect of reinventing potential on entrepreneurial character, is 0.57 with a probability value of 0.000 , much smaller than 0.05 , which means that the potential for reinventing has a significant effect on the character of millennial entrepreneurship at the $1 \%$ significance level. The high social media intensity coefficient value has the effect of reinventing potential on the entrepreneurial character of 0.40 with a probability value of 0,000 which is much smaller than 0.05 , meaning that reinventing potential has a significant effect on the entrepreneurial character of the millennials at $1 \%$ significance level. Because the two probability values are significant both at low social media intensity and high social media intensity, it can be concluded that social media does not moderate (does not strengthen) the effect of potential reinventing on the entrepreneurial character of the millennial generation in Indonesia.

2. The coefficient value of low social media intensity, the effect of financial independence on entrepreneurial character, is 0.17 with a probability value of 0,000 which is much smaller than 0.05 , meaning that financial independence has a significant effect on the entrepreneurial character of the millennial generation in Indonesia at the $1 \%$ level of significance. The coefficient value of high social media intensity, the effect of financial independence on entrepreneurial character, is 0.04 with a probability value of 0.60 , which is much greater than 0.05 , meaning that financial freedom has no significant effect on the entrepreneurial character of the millennial generation in Indonesia. Because there is a significant difference between the value of low social media intensity (significant) and high social media intensity (not significant), it can be concluded that social media moderates (strengthens) the effect of financial independence on the entrepreneurial character of the millennial generation in Indonesia.

\section{CONCLUSION}

To foster entrepreneurial character among the millennial generation, it can be pursued through reinventing the potential of the millennial generation. The desire for financial freedom also encourages the growth of entrepreneurial interest in the millennial generation. In addition, social 


\section{ORFAI JOURNAL Multidiciplinary Output Research For Actual and International Issue}

media is an important factor that can strengthen the growth of the entrepreneurial character of the millennial generation. Given that reinventing potential activities, the desire for financial freedom, and social media are important factors in shaping entrepreneurial character, stakeholders: government, business groups, and universities must be able to adjust programs, policies, and curriculum that can support the growth of entrepreneurial character among the millennial generation.

\section{REFERENCES}

Alharethi, M. A. (2016). Using Instagram for shopping in Saudi Arabia (Doctoral, dissertation, Arkansas State University).

Ambarwati, 2020, Membangun Jiwa Kewirausahaan Di Era Milenial Bagi ahasiswa Institut Stiami Kampus Tangerang, Jakarta, Jurnal Komunitas Jurnal Pengabdian kepada Masyarakat Vol. 2, No. 2, Januari,

Assegaff, Setiawan. "Evaluasi Pemanfaatan Media Sosial sebagai Sarana Knowledge Sharing", Bandung, Jurnal Manajemen Teknologi,

Atmoko, BambangDwi. (2012). Instagram Handbook. Jakarta: Gramedia Pustaka Umum.

Badan Pusat Statistik. 2019. Statistik Gender, Tematik: Profil Generasi Milenial Indonesia Jakarta, Badan Pusat Statistik

Che, J. W., Cheung, C. M., \& Thadani, D. R. (2017, January). Consumer Purchase Decision in Instagram Stores: The Role of Consumer Trust. In Proceedings of the 50th Hawaii International Conference on System Sciences.

D. Juju, (2008), Gaya Gaul Anak Muda dengan Facebook, Elex Media Komputindo

David Osborne dan Ted Gaebler, (1996) Mewirausahakan Birokrasi, terj. Abdul Rasyid, Jakarta: Pustaka Binaman Pressindo

Dwijayanti, Renny. 2015. "Pengaruh pendidikan kewirausahaan, locus of control, dan kebutuhan berprestasi terhadap pembentukan sikap kewirausahaan mahasiswa". "jurnal ekonomi" Vol 3, No 1, hal 171-180.

Geoffrey G. Meredith dkk. 1996. kewirausahaan teori dan Praktek. Jakarta: PT Pustaka Binaman Presindo.

Gibbons, S. (2007). Redefining the roles of information professionals in higher education to engage the net generation., Australasia, Paper Presented at EDUCAUSE,

Hair, J.F., Money, A.H., Samouel, P., \& Page, M. (2007), Research Methods for Business,Penerbit John Wiley \& Sons, Ltd. England.

Haryanto, (2019), Strategi Promosi Melalui Media Sosial Instagram Guna Menarik Generasi Milenial untuk Memilih Produk Tabungan Pada PT Bank Pembangunan Daerah Kalimantan Selatan, Banjarmasin, Inovbis

Hasan, Muhammad. 2018. Pembinaan Ekonomi Kreatif dalam Perspektif Pendidikan Ekonomi. Jurnal Ekonomi dan Pendidikan (JEKPEND) Volume 1, No. 1 Januari 2018 p-ISSN: 26142139; e-ISSN: 2614-1973.

Hausman, A. V., \& Siekpe, J. S. (2009). The effect of web interface features on consumer online purchase intentions. Journal of Business Research

Helsper \& Enyon (2009).Influence of age and training on planning instruction using mobiles phones by pre-service social studies teachers, Nigeria, British educational research journal. 
The Effect of Reinventing Potential and Financial Independence on the Entrepreneurs Character of Millennials Through Social Media in the Era Marketing 4.0

DOI: $10.54443 /$ morfai.v1i2.104

Helsper, E., \& Enyon, R. (2009). Digital natives: Where is the evidence? British Educational Research Journal, 1-18.

https://www.akseleran.co.id/blog/finansial, diakses 20 Juli 2020,

Irawan ari. 2016. "Journal of business management of entrepreneurship education". "Jurnal ekonomi”. Volume 1, number 1, April 2016, hal 213-223.

Jacob Lund Fisker (2010) Early Retirement Extreme: A philosophical and practical guide to financial independence, ISBN 978-1453601211

Kearney, 2000, Reinventing Government: City Manager Attitudes and Actions, Public Administration Review, Vol. 60 No. 6, (2000).

Kemp, S. (2018). Digital in 2018: World's internet users pass the 4 billion mark.

Kompas.com, 2019, Bagaimana Menuju Kebebasan Finansial?",https://money.kompas.com/read/l.

Kotler, Philip and Keller Lane Kevin, 2018., Marketing Management, $14^{\text {th }}$ edition., Pearson Education.Inc.

L. Patria dan K. Yulianto, (2010) Pemanfaatan Facebook Untuk Menunjang Kegiatan Belajar Mengajar Online Secara Mandiri. [online] http://www.pustaka.ut.ac.id

Laudon, K. J. \& Laudon, J. P. (2012). "Management Information Systems: Managing the Digital Firm”, Boston, USA Prentice Hall

Mashuda, 2019, Tinjauan Regulasi Tol Berdasarkan Teori Reinventing, UI Depok Jakrta, Rechts Vinding Journal,

Meredith Geoffrey. 2002. Kewirausahaan, Teori, dan Praktek. Jakarta, CV. Taruna Grafika

Mizz Farha Diba, 2019, Menjadi Entrepreneur di Era-Digital, Kota Tangerang Selatan, Jurnal Komunitas

Mutis Thoby. 1995. Kewirausahaan yang Berproses. Jakarta. Gramedia Widiasarana Indonesia.

Osborne, David, (2007) Reinventing Government: What A Difference A Strategy Makes. Makalah yang disampaikan pada 7th Global Forum on Reinventing Government Building Trust in Government 26-29 June 2007, Vienna, Austria. 7h Global Forum on Reinventing Government Building Trust in Governmen

Perdana, 2019, Generasi Milenial dan Strategi Pengelolaan SDM Era Digital, Yogyakarta Jurnal Studi Pemuda Volume 8 Nomor 1 tahun,

Sekaran, U. 2000. Research Methods for Business: A Skill Building Approach, 3rd ed., New York: John Wiley \& Sons, Inc

Student's Column, 2019, Era globalisasi menuntut generasi milenial berjiwa entrepreneur

Suharyanto, 2016, Komunikasi Digital Whatsapp dalam Pengembangan Layanan diKepustakaan, Proseding Seminar Nasional, Generasi Digital Native, Bandung SLiMS Commeet West Java,

Taken Smith, K. (2012). Longitudinal study of digital marketing strategies targeting

Tapscott, D. (2009). Grown up digital: How the net generation is changing your world. New York, US: McGraw-Hill.

Tiago, M. T. P. M. B., \& Veríssimo, J. M. C. (2014). Digital marketing and social media: Why bother? Business Horizons, Millennials. Journal of Consumer Marketing, 
Vicki, Robin \& Joe, Dominguez (1992) Your Money or Your Life, Viking. Your Money or Your Life: Revised and Updated for the 21st Century, published by Penguin Books in December 2008 by Vicki Robin with Monique Tilford and contributor Mark Zaifman.

Wibowo, 2020, Peluang Revolusi Industri 4.0 Bidang Pemasaran: Pemanfaatan Aplikasi Ecommerce, Sosial Media Instagram dan Digital Marketing terhadap keputusan Instant Online Buying Konsumen Generasi Millenia, Yogyakarta, Jurnal Ekonomi dan Manajemen,

Zarella, Dan. 2010. The Social Media Marketing Book. Canada: O’Relly Media. Inc.

Ziveria, Mira, (2017), Pemanfaatan Media Sosial Facebook Sebagai Sarana Efektif Pendukung Kegiatan Perkuliahan di Program Studi Sistem Informasi Institut Teknologi dan Bisnis Kalbe, Jakarta, Jurnal Sains and Technology 
Volume 1 No 2 (2021)

The Effect of Reinventing Potential and Financial Independence on the Entrepreneurs Character of Millennials Through Social Media in the Era Marketing 4.0

DOI: $10.54443 /$ morfai.v1i2.104 